\title{
Poly(Methyl Methacrylate) Coatings Containing Flame Retardant Additives from Suspensions in Water-2-Propanol
}

\author{
Xuelin Li ${ }^{1}$, Zhengzheng Wang ${ }^{1}$, Sadman Sakib ${ }^{2}$, Ritch Mathews ${ }^{3}$ and Igor Zhitomirsky ${ }^{1, *}$ \\ 1 Department of Materials Science and Engineering, McMaster University, Hamilton, ON L8S4L7, Canada; \\ lix387@mcmaster.ca (X.L.); wangz338mcmaster.ca (Z.W.) \\ 2 Department of Engineering Physics, McMaster University, Hamilton, ON L8S4L7, Canada; \\ sakibs@mcmaster.ca \\ 3 Advanced Ceramics Corporation, 2536 Bristol Circle, Oakville, ON L6H5S1, Canada; rmathews@acc.ca \\ * Correspondence: zhitom@mcmaster.ca
}

Citation: Li, X.; Wang, Z.; Sakib, S.; Mathews, R.; Zhitomirsky, I. Poly(Methyl Methacrylate) Coatings Containing Flame Retardant Additives from Suspensions in Water-2-Propanol. Molecules 2021, 26, 1974. https://doi.org/10.3390/ molecules26071974

Academic Editor: Joannis K. Kallitsis

Received: 24 February 2021

Accepted: 26 March 2021

Published: 31 March 2021

Publisher's Note: MDPI stays neutral with regard to jurisdictional claims in published maps and institutional affiliations.

Copyright: (C) 2021 by the authors. Licensee MDPI, Basel, Switzerland. This article is an open access article distributed under the terms and conditions of the Creative Commons Attribution (CC BY) license (https:/ / creativecommons.org/licenses/by/ $4.0 /)$.

\begin{abstract}
A dip-coating technique is designed for deposition of poly(methyl methacrylate) (PMMA) from water/2-propanol mixture, avoiding the use of traditional toxic solvents. Solutions of PMMA macromolecules with high molecular weight $\left(\mathrm{M}_{\mathrm{W}}\right)$ are obtained for a water/2-propanol ratio of $0.15-0.33$ and the solubilization mechanism is discussed. The ability to use concentrated PMMA solutions and high $\mathrm{M}_{\mathrm{W}}$ of the polymer are the key factors for the successful dip coating deposition. The coating mass for $10 \mathrm{~g} \mathrm{~L}^{-1}$ polymer solutions shows a maximum at a water/2-propanol ratio of 0.25 . The deposition yield increases with the polymer concentration increase and with an increasing number of the deposited layers. PMMA deposits protect stainless steel from aqueous corrosion. The coating technique allows for the fabrication of composite coatings, containing flame-retardant materials (FRMs), such as commercial halloysite, huntite, hydrotalcite, and synthesized $\mathrm{Al}(\mathrm{OH})_{3}$, in the PMMA matrix. The FRM content in the coatings is modified by variation of the FRM content in colloidal suspensions. A fundamentally new method is developed, which is based on the salting out aided dispersive extraction of $\mathrm{Al}(\mathrm{OH})_{3}$ from the aqueous synthesis medium to 2-propanol. It is based on the use of hexadecylphosphonic acid molecules as extractors. The method offers advantages of reduced agglomeration.
\end{abstract}

Keywords: poly(methyl methacrylate); huntite; halloysite; hydrotalcite; hydroxide; coating

\section{Introduction}

Poly(methyl methacrylate) (PMMA) coatings are widely used for protection of metals from aqueous corrosion, surface modification of biomedical implants, fabrication of solar cells, batteries and supercapacitors, optical devices, and biosensors [1]. PMMA exhibits good chemical stability and mechanical properties, biocompatibility, and thermal stability [1]. The selection of solvents for PMMA is important for coating deposition techniques, such as electrophoretic deposition, dip coating, spin coating, and spray-coating. PMMA is well-soluble in benzene, toluene, and methyl ethyl ketone, which are carcinogenic and toxic. Therefore, there is a need to avoid the use of such solvents for the fabrication of PMMA coatings.

Flame retardant materials (FRMs) are usually added to PMMA and other polymers to meet safety regulations [2]. However, many common FRMs, such as halogen- and phosphate-based FRMs, are toxic and bioaccumulative [2,3]. Investigations showed that the use of halogen-based FRMs resulted in widespread contamination of the environment $[4,5]$. Therefore, halogenated FRMs must be replaced by environmentally friendly FRMs [2].

Natural minerals, such as halloysite, huntite, and hydrotalcite, are promising FRMs. Aluminum hydroxide is a low-cost FRM additive for various FR applications. The FR properties of such materials are attributed to endothermic decomposition and release of $\mathrm{H}_{2} \mathrm{O}$ or $\mathrm{CO}_{2}$, which dilute fuel. Thermal analysis of halloysite showed mass loss of about 
$18 \%$ related to dehydration and related endothermic effect [6,7]. Halloysite is an important FRM additive for different polymers [6,7]. Natural halloysite forms nanotubes, which can reinforce polymer materials [7,8]. Moreover, halloysite nanotubes can be loaded with other functional materials, such as corrosion inhibitors [9]. Huntite is another advanced FRM additive for different polymers, because it is a naturally available mineral [10-13]. It is a halogen-free, non-corrosive, and recyclable FRM [10]. Many investigations focused on the analysis of thermal behavior of huntite $[10,12,13]$, which showed mass loss related to $\mathrm{CO}_{2}$ gas release of about $50 \%$. The relatively high mass loss related to thermal decomposition of huntite and a significant endothermic effect are important factors for the FRM applications of this material. Huntite has a relatively high thermal decomposition temperature [12,13], which is higher than the processing temperatures of important thermosetting polymer products. Therefore, huntite can be added to thermosetting polymers. The interest in the fabrication of polymer composites containing hydrotalcite is attributed to the excellent FRM properties of this material, such as significant water release due to its thermal dehydration and the related endothermic effect. Many investigations focused on the analysis of thermal properties of hydrotalcite at different conditions and fabrication of polymer-hydrotalcite composites [14-16]. It was found that thermal decomposition of hydrotalcite results in mass loss of $43 \%$, which is related to the release of $\mathrm{H}_{2} \mathrm{O}$ and $\mathrm{CO}_{2}$. Aluminum hydroxide decomposition results in mass loss of $35 \%$, which is solely related to $\mathrm{H}_{2} \mathrm{O}$ release. In contrast to huntite and hydrotalcite, the release of $\mathrm{CO}_{2}$ can be avoided. The significant water release related to its thermal dehydration makes $\mathrm{Al}(\mathrm{OH})_{3}$ a promising material for many FRM applications [17,18]. Previous investigations highlighted the need for a uniform distribution of non-agglomerated $\mathrm{Al}(\mathrm{OH})_{3}$ nanoparticles in a polymer matrix for the deposition of high-quality composites, containing $\mathrm{Al}(\mathrm{OH})_{3}$ as an FRM additive.

The objective of this work was the deposition of PMMA and composites, containing inorganic FRM additives, such as halloysite, huntite, hydrotalcite, and $\mathrm{Al}(\mathrm{OH})_{3}$, avoiding the use of carcinogenic and toxic organics, such as organic solvents and organic FRM additives. FRMs are mandatory additives for various polymer products for the reduction of polymer flammability. Inorganic FRM additives represent a promising alternative to toxic halogenated FRMs. Moving towards the objective of this work, we analyzed the PMMA solubility in water-2-propanol co-solvent with different water contents and optimized the deposition yield in various experimental conditions. We developed a fundamentally new approach, which involved synthesis of $\mathrm{Al}(\mathrm{OH})_{3}$ nanoparticles by an aqueous precipitation method, their salting out aided dispersive extraction to 2-propanol, and fabrication of $\mathrm{Al}(\mathrm{OH})_{3}$ dispersions in PMMA solutions using water-2-propanol for coating application. The method facilitates agglomerate-free processing of hydroxide nanoparticles. It is conceptually different from other particle extraction techniques [19] and can potentially be used for dispersive extraction of various functional materials.

\section{Results and Discussion}

PMMA is insoluble in water and 2-propanol at room temperature. However, we found that high-molecular-mass PMMA was soluble in different water-2-propanol mixtures with a water/2-propanol ratio of $R_{\text {wip }}=0.15-0.33$. First, $10 \mathrm{~g} \mathrm{~L}^{-1}$ PMMA solutions were prepared using solvent compositions in the range of $0.15<\mathrm{R}_{\text {wip }}<0.33$. However, PMMA precipitation was observed at $R_{\text {wip }}<0.15$ and $R_{\text {wip }}>0.33$. The highest PMMA solubility of $20 \mathrm{~g} \mathrm{~L}^{-1}$ was achieved at $R_{\text {wip }}=0.25$. However, the solubility decreased with decreasing or increasing $\mathrm{R}_{\text {wip }}$.

The ability to form relatively concentrated PMMA solutions using a high $\mathrm{M}_{\mathrm{W}}$ polymer was crucial to the PMMA deposition by dip-coating and avoiding the use of carcinogenic and toxic organic solvents. Water-alcohol mixtures were used as co-solvents for low $\mathrm{M}_{\mathrm{W}}$ PMMA [20] at essentially lower polymer concentrations. However, low $\mathrm{M}_{\mathrm{W}}$ PMMA exhibits poor adhesion and inferior ability to form good-quality coatings. Usually, the increase of polymer $\mathrm{M}_{\mathrm{W}}$ leads to decreasing solubility due to stronger interactions of larger polymer macromolecules. 
It is known [20] that water and alcohols contribute to PMMA solvation because they interact with different structural groups of the polymer. At a low $\mathrm{H}_{2} \mathrm{O}$ content, individual $\mathrm{H}_{2} \mathrm{O}$ molecules can be involved in the H-bonding to the PMMA carbonyl ligands [20]. The increase in $\mathrm{H}_{2} \mathrm{O}$ content leads to $\mathrm{H}_{2} \mathrm{O}$ clustering, where $\mathrm{H}$-bonding is preferably created between individual $\mathrm{H}_{2} \mathrm{O}$ molecules and such clustering prevents the $\mathrm{H}_{2} \mathrm{O}$ bonding to the carbonyl ligands [21]. As a result, the PMMA solubility decreased for $\mathrm{H}_{2} \mathrm{O}$ content $\mathrm{R}_{\text {wip }}>0.25$. The PMMA precipitation at $\mathrm{R}_{\text {wip }}<0.25$ is related to poor PMMA solvation due to lower $\mathrm{H}_{2} \mathrm{O}$ content in the solvent [22]. The analysis of the coating mass for $10 \mathrm{~g} \mathrm{~L}^{-1}$ solutions of PMMA revealed a maximum at $R_{\text {wip }}=0.25$ (Figure $1 \mathrm{~A}$ ). The coating mass increased with the growing concentration of PMMA in the interval of $0.5-20 \mathrm{~g} \mathrm{~L}^{-1}$ for $R_{\text {wip }}=0.25$ (Figure 1B). The deposition yield was low at PMMA concentrations $0.5-5 \mathrm{~g} \mathrm{~L}^{-1}$. The highest PMMA solubility of $20 \mathrm{~g} \mathrm{~L}^{-1}$ was achieved only at $R_{\text {wip }}=0.25$. Therefore, further investigations were performed at a PMMA concentration of $10 \mathrm{~g} \mathrm{~L}^{-1}$. The coating adhesion measured according to ASTM D3359-17 standard corresponded to 5B classification. PMMA films can be obtained as monolayers or multilayers. The coating mass increased with an increasing number of individual layers (Figure 1C). Therefore, the mass of the deposits can be changed by variation of $R_{\text {wip }}$, concentration of PMMA, and number of individual layers. FRM materials were added to the PMMA solutions and obtained colloidal suspensions were applied for the deposition of composites. The FRM suspensions containing FRM were stable for more than 3 days. The increase of coating mass with increasing FRM concentration (Figure 1D) indicated the formation of composite coatings with different FRM contents. A significant increase in the coating mass with an increasing FRM concentration at a constant PMMA concentration in the slurry indicated that coatings with an FRM content in a wide range can be prepared.
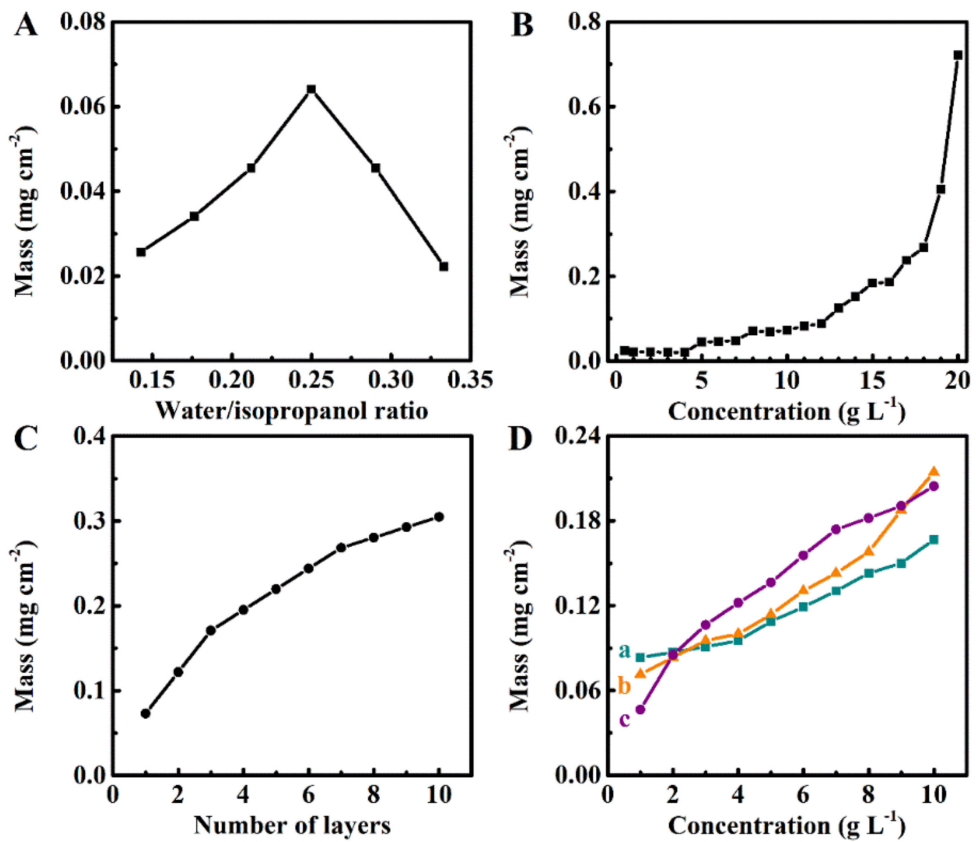

Figure 1. (A) Coating mass versus water/2-propanol ratio ( $\left.R_{\text {wip }}\right)$ at a poly(methyl methacrylate) (PMMA) concentration of $10 \mathrm{~g} \mathrm{~L}^{-1}$, (B) coating mass versus PMMA concentration in a solution with $R_{\text {wip }}=0.25,(\mathbf{C})$ coating mass versus number of individual layers deposited from $10 \mathrm{~g} \mathrm{~L}^{-1}$ PMMA solutions with $R_{\text {wip }}=0.25$, (D) coating mass versus the concentration of commercial flame-retardant materials (FRMs): (a) halloysite, (b) huntite, and (c) hydrotalcite in $10 \mathrm{~g} \mathrm{~L}^{-1}$ solutions of PMMA for $\mathrm{R}_{\text {wip }}=0.25$.

Figure 2 presents SEM images of a monolayer PMMA coating prepared from $10 \mathrm{~g} \mathrm{~L}^{-1}$ solutions of PMMA at $\mathrm{R}_{\text {wip }}=0.25$. The deposition technique facilitated the fabrication of crack-free layers, which contained a relatively dense bottom layer and a porous top layer. 
The coating thickness was $\sim 2 \mu \mathrm{m}$. The PMMA deposits showed protection of stainless steel from aqueous corrosion.
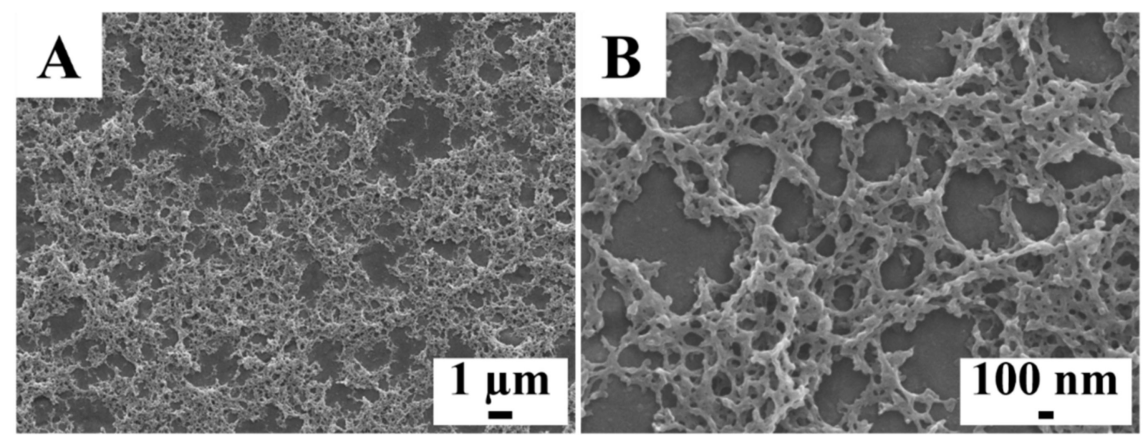

Figure 2. (A,B) SEM images at different magnifications of a coating fabricated using $10 \mathrm{~g} \mathrm{~L}^{-1}$ solution of PMMA with $R_{\text {wip }}=0.25$.

Figure 3 shows the results of potentiodynamic and electrochemical impedance spectroscopy (EIS) investigations. The substrates containing the deposited PMMA layer showed a lower corrosion current $\left(i_{\mathrm{c}}\right)$ and higher corrosion potential. It was found that $i_{\mathrm{c}}$ was $2.6 \mu \mathrm{A} \mathrm{cm}^{-2}$ for the uncoated substrate and $i_{\mathrm{c}}$ reduced to $0.025 \mu \mathrm{A} \mathrm{cm}{ }^{-2}$ after PMMA deposition. EIS testing (Figure 3) revealed that the PMMA layer served as a barrier, limiting ion access to the surface. Coated samples exhibited essentially higher impedance $|\mathrm{Z}|$ (Figure $3 \mathrm{~B}$ ) than uncoated substrates due to high electrical resistance and low electrical capacitance of the PMMA layer. In contrast, the uncoated substrates showed low $|\mathrm{Z}|$ due to low resistance and high capacitance of the electrical double layer.
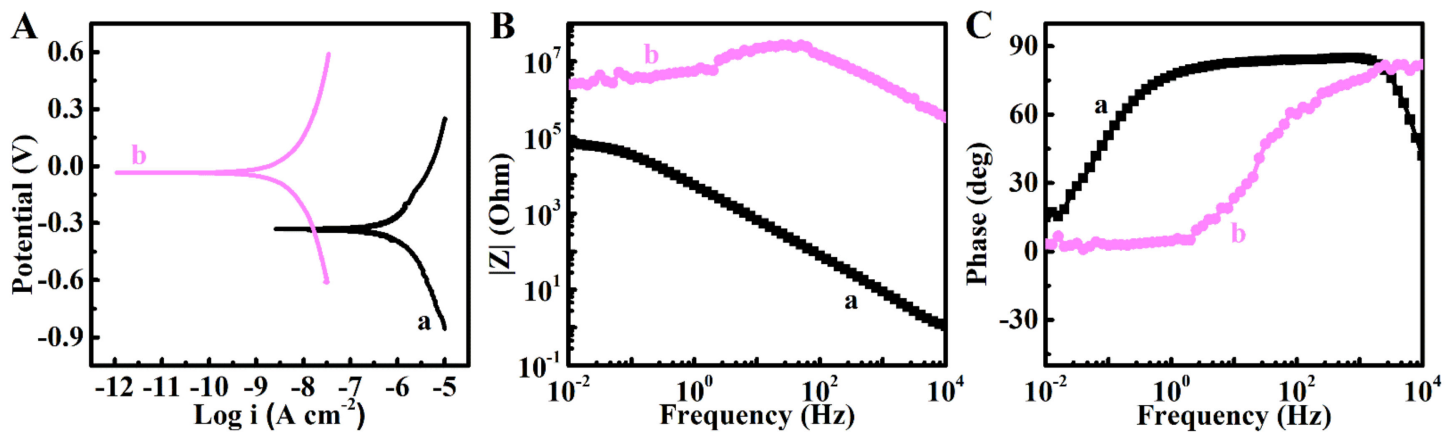

Figure 3. (A) Tafel dependences, and (B,C) Bode graphs for (a) uncoated substrate and (b) substrate coated with PMMA. The coating was prepared from $10 \mathrm{~g} \mathrm{~L}^{-1}$ solution of PMMA with $\mathrm{R}_{\text {wip }}=0.25$. Testing was performed in aqueous $3 \% \mathrm{NaCl}$ using saturated calomel electrode as a reference.

SEM studies (Figure 4) showed that composite coatings were deposited from the $10 \mathrm{~g} \mathrm{~L}^{-1}$ solutions of PMMA with $1-10 \mathrm{~g} \mathrm{~L}^{-1}$ FRM. The increase in FRM content above $5 \mathrm{~g} \mathrm{~L}^{-1}$ led to significant porosity of the composite coatings. Figure 4 presents SEM data for the deposits formed from the $10 \mathrm{~g} \mathrm{~L}^{-1}$ solutions of PMMA with $10 \mathrm{~g} \mathrm{~L}^{-1}$ FRM. The SEM images at low magnification show the deposition of crack-free layers. The images at high magnification show halloysite nanotubes (Figure 4B), huntite platelets (Figure 4D), and submicrometre hydrotalcite particles (Figure 4F). The porosity at high FRM concentrations was a result of the packing of the FRM particles. Similar to other colloidal techniques [23,24], the rugosity of the coatings was influenced by the size of particles used. The incorporation of the FRM into the PMMA coating was also supported by XRD and FTIR studies. XRD studies of the composite coating (Figure 5A) showed peaks corresponding to JCPDS files 090453, 14-0409, and 50-1684 of halloysite, huntite, and hydrotalcite, respectively (Figure 5A). The FTIR spectrum of PMMA (Figure 5B) and spectra of the composite materials (Figure 5C) showed peaks at $1149 \mathrm{~cm}^{-1}$ due to symmetric C-O-C stretching, $1439 \mathrm{~cm}^{-1}$ due to $\mathrm{CH}_{2}$ 
bending, $1721 \mathrm{~cm}^{-1}$ due to $\mathrm{C}=\mathrm{O}$ stretching, and $2951 \mathrm{~cm}^{-1}$ due to asymmetric $\mathrm{CH}_{3}$ stretching [25]. The FTIR data for as-received halloysite (Figure 5B) and PMMA-halloysite (Figure 5C) showed broad absorptions at 1016, 907, and $531 \mathrm{~cm}^{-1}$ assigned to stretching mode $\mathrm{Si}-\mathrm{O}-\mathrm{Si}$, bending vibrations of $\mathrm{Al}-\mathrm{OH}$, and bending and stretching vibrations of Si-O-Al [26], respectively.
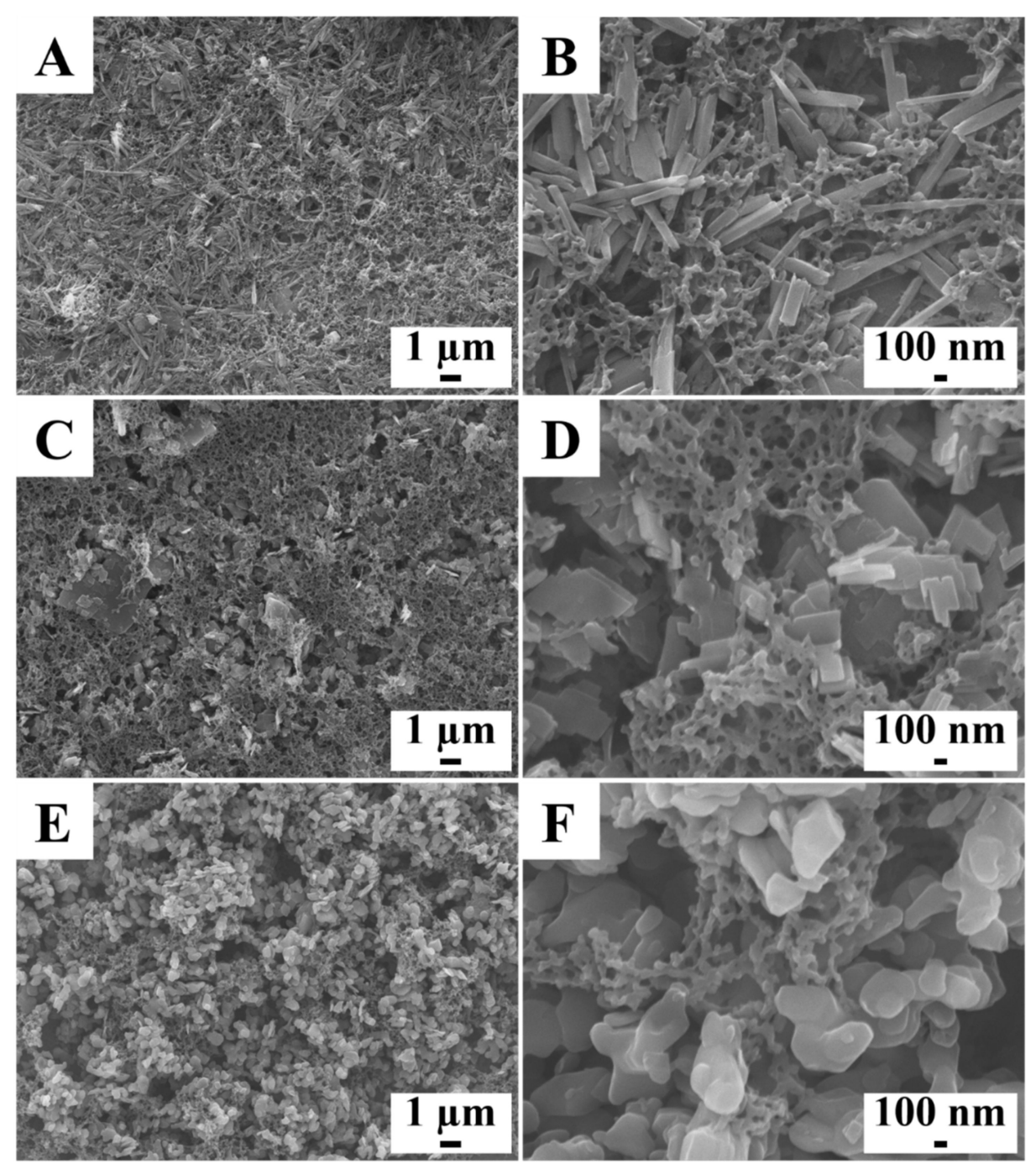

Figure 4. SEM images for (A,B) PMMA-halloysite, (C,D) PMMA-huntite, and (E,F) PMMA-hydrotalcite coatings, prepared from $10 \mathrm{~g} \mathrm{~L}^{-1}$ solutions of PMMA with $R_{\text {wip }}=0.25$, containing $10 \mathrm{~g} \mathrm{~L}^{-1}$ FRM.

The spectra of huntite (Figure 5B) and PMMA-huntite (Figure 5C) showed characteristic absorptions [13] at 865 and $889 \mathrm{~cm}^{-1}$, attributed to carbonate ligands. The spectra of hydrotalcite (Figure 5B) and PMMA-hydrotalcite (Figure 5C) showed peaks at $1367 \mathrm{~cm}^{-1}$ related to asymmetric stretching of the carbonate and at 551,662 , and $773 \mathrm{~cm}^{-1}$ related to oxygen-metal-oxygen stretching [27]. 

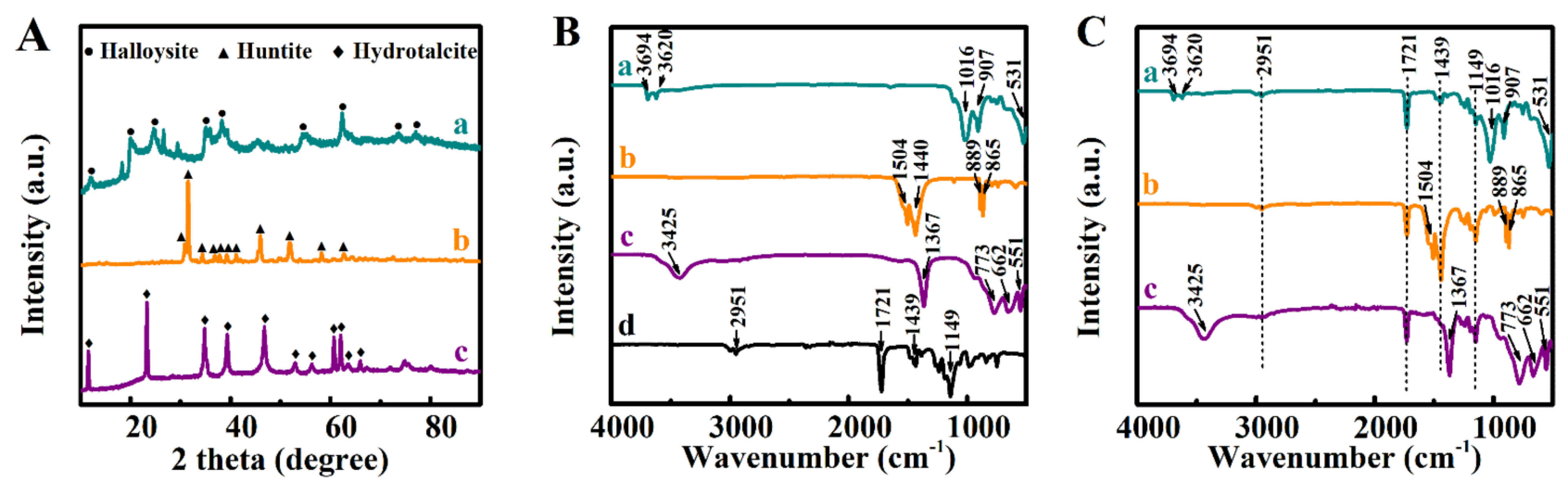

Figure 5. (A) X-ray diffraction patterns of the deposits obtained from $10 \mathrm{~g} \mathrm{~L}^{-1}$ solutions of PMMA with $\mathrm{R}_{\text {wip }}=0.25$, containing $10 \mathrm{~g} \mathrm{~L}^{-1}$ FRM additives: (a) halloysite, (b) huntite, and (c) hydrotalcite, (B,C) FTIR spectra of (B) as-received materials: (a) halloysite, (b) huntite (c) hydrotalcite, and (d) PMMA; (C) coating prepared from $10 \mathrm{~g} \mathrm{~L}^{-1}$ solutions of PMMA with $\mathrm{R}_{\text {wip }}=0.25$, containing $10 \mathrm{~g} \mathrm{~L}^{-1}$ FRM additives: (a) halloysite, (b) huntite, (c) hydrotalcite.

The ability to use water-2-propanol mixtures for the fabrication of PMMA solutions was one of the key factors for the development of a new approach for the fabrication of composite coatings. Another factor was the ability to separate 2-propanol from its mixture with water by a salting out method [28,29]. In this work, $\mathrm{Al}(\mathrm{OH})_{3}$ was prepared by a chemical precipitation from an aqueous solution of $\mathrm{Al}_{2}\left(\mathrm{SO}_{4}\right)_{3}$. The obtained powder was washed, dried, and studied by XRD. It was found that the obtained powder was amorphous and contained agglomerated particles. In a previous investigation [19], different agglomeration mechanisms related to the drying stage were described and strategies were developed for the avoiding drying stage and transferring nanoparticles formed in water to a water immiscible organic phase via the liquid-liquid boundary. The major driving forces for agglomeration during the drying stage are reduction of the surface area of the particles and condensation of the surface $\mathrm{OH}$ groups, which results in oxygen bridges between the particles. Therefore, drying of the $\mathrm{Al}(\mathrm{OH})_{3}$ particles prepared in an aqueous media resulted in significant particle agglomeration. It is challenging to redisperse such particles in the coating processing media. Previous investigations [19] demonstrated the possibility of reduced agglomeration of particles by their surface modification and direct transfer from aqueous suspensions to an organic suspensions for coating or device fabrication.

The approach developed in this investigation is conceptually different from other particle extraction techniques [19]. It involves the application of 2-propanol as an organic solvent, which was mixed with water (Figure 6). The addition of 2-propanol, containing dissolved hexadecylphosphonic acid (HDPA), to the aqueous suspension of as-precipitated $\mathrm{Al}(\mathrm{OH})_{3}$ particles allowed particle modification and dispersion in a mixed water-2-propanol solvent. The modification of particles in bulk suspensions is more efficient, compared to the modification at the interface of immiscible liquids [19], where particles must be transferred to the liquid-liquid interface from an aqueous phase, whereas extractors must be transferred to the interface from an organic phase. In our investigation, HDPA was used as a dispersant and extractor for the $\mathrm{Al}(\mathrm{OH})_{3}$ particles. The addition of $\mathrm{NaCl}$ allowed the separation of the 2-propanol phase, containing dispersed $\mathrm{Al}(\mathrm{OH})_{3}$ nanoparticles, from their suspension in the water-2-propanol mixture (Figure 6A,B). It is important to note that in experiments performed without $\mathrm{HDPA}$, the $\mathrm{Al}(\mathrm{OH})_{3}$ particles remained in the aqueous phase. Therefore, the surface functionalization of $\mathrm{Al}(\mathrm{OH})_{3}$ particles with HDPA was critically important for their transfer to 2-propanol. Moreover, the adsorbed HDPA facilitated the fabrication of stable $\mathrm{Al}(\mathrm{OH})_{3}$ suspension in 2-propanol (Figure 6B). The chemical structure of HDPA is presented in Figure 6C. It contains phosphonate and hydrocarbon groups. It is known [30] that the phosphonate group facilitates strong bonding to the metal surface atoms of the inorganic particles by chelating or bridging bonding mechanisms (Figure 6D). The hydrocarbon group of adsorbed HDPA facilitated particle dispersion and transfer to 2-propanol. 
$\mathbf{A}$

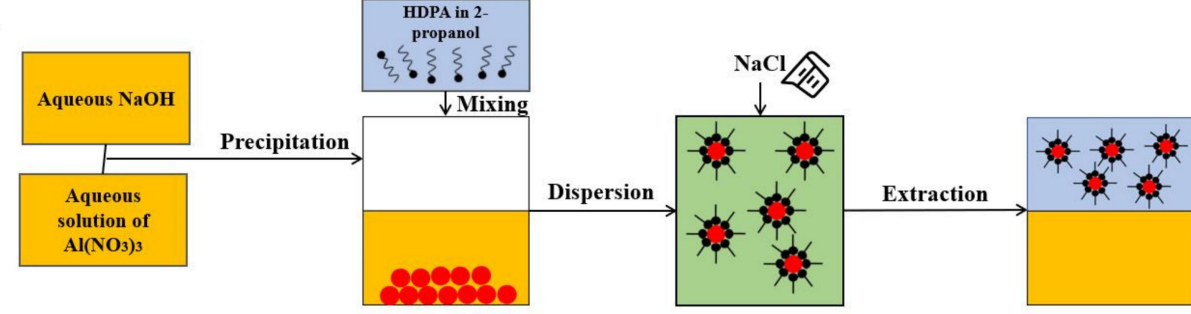

B

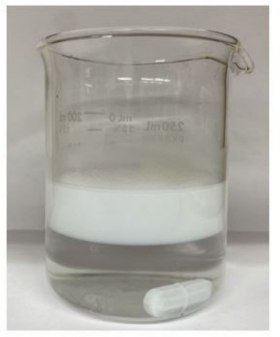

C

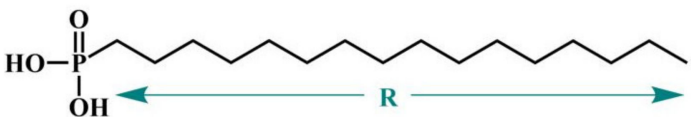

D

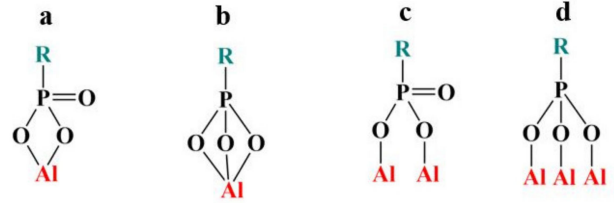

Figure 6. (A) Synthesis and salting out dispersive extraction of $\mathrm{Al}(\mathrm{OH})_{3}$ particles, (B) extraction of HDPA dispersed $\mathrm{Al}(\mathrm{OH})_{3}$ particles to 2-propanol, (C) HDPA structure, (D) HDPA adsorption mechanisms, involving $(\mathbf{a}, \mathbf{b})$ chelating or $(\mathbf{c}, \mathbf{d})$ bridging.

The obtained $\mathrm{Al}(\mathrm{OH})_{3}$ dispersion in 2-propanol was used for the fabrication of $\mathrm{Al}(\mathrm{OH})_{3}$ dispersion in a mixed water-2-propanol solvent $\left(\mathrm{R}_{\text {wip }}=0.25\right)$ containing dissolved PMMA. Such suspensions were utilized for the fabrication of PMMA-Al(OH $)_{3}$ coatings. The formation of composite coatings was confirmed by SEM and FTIR. SEM studies (Figure 7A) showed that the surface layer of the coatings exhibited a porous fibrous microstructure, similar to that observed for pure PMMA (Figure 2A). However, at higher magnification (Figure 7B), nanoparticles of $\mathrm{Al}(\mathrm{OH})_{3}$ were observed with a typical size of 30-50 nm. The particles showed very low agglomeration due to the salting out dispersive extraction method developed in this investigation.

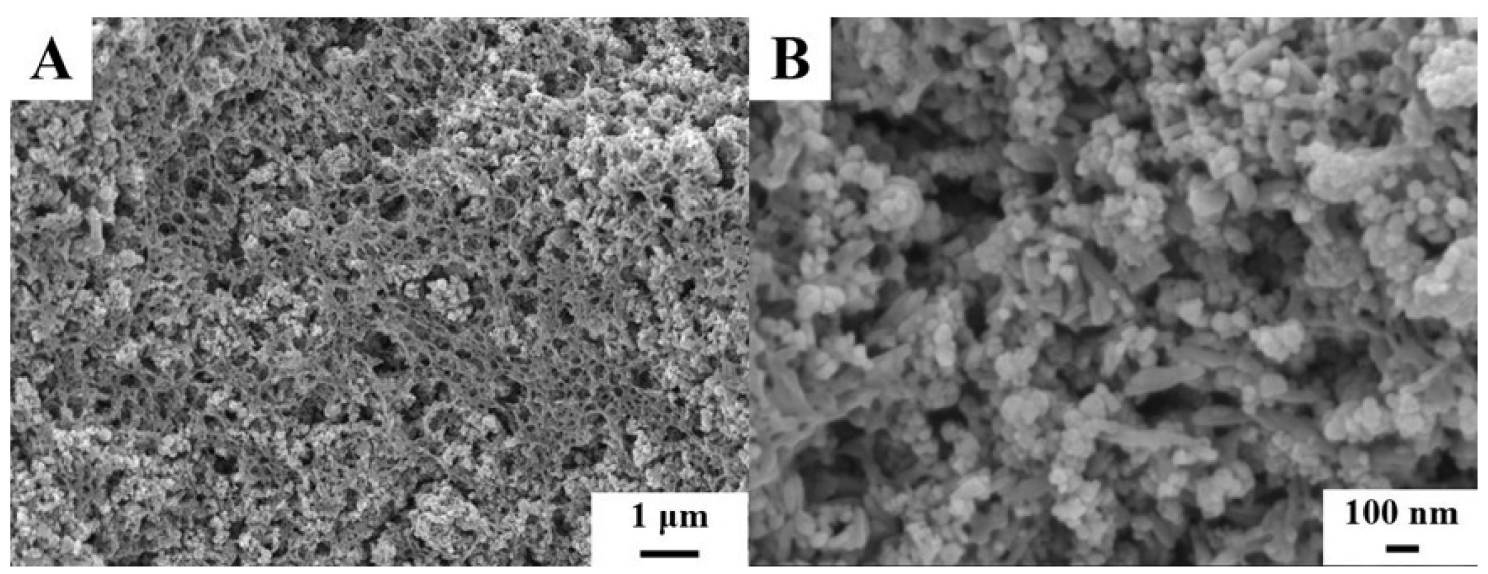

Figure 7. (A,B) SEM images at different magnifications for the PMMA-Al(OH $)_{3}$ coatings, prepared from $10 \mathrm{~g} \mathrm{~L}^{-1}$ solutions of PMMA with $\mathrm{R}_{\text {wip }}=0.25$, containing $5 \mathrm{~g} \mathrm{~L}^{-1} \mathrm{Al}(\mathrm{OH})_{3}$ using salting out aided dispersive extraction of $\mathrm{Al}(\mathrm{OH})_{3} \mathrm{particles}$.

Figure 8 presents the FTIR spectra of the as-precipitated $\mathrm{Al}(\mathrm{OH})_{3}$, as-received HDPA, composite PMMA-Al $(\mathrm{OH})_{3}$ coating, and extracted $\mathrm{Al}(\mathrm{OH})_{3}$. The FTIR spectrum of the as-precipitated $\mathrm{Al}(\mathrm{OH})_{3}$ shows a broad absorption at $3430 \mathrm{~cm}^{-1}$ due to hydroxyl stretch; small absorptions at 1640,1509 , and $1428 \mathrm{~cm}^{-1}$ due to bending of adsorbed $\mathrm{H}_{2} \mathrm{O}, \mathrm{Al}-$ $\mathrm{O}$ stretching, and Al-O bending, respectively; and a broad absorption below $650 \mathrm{~cm}^{-1}$ due to various $\mathrm{O}-\mathrm{Al}-\mathrm{O}, \mathrm{Al}-\mathrm{O}-\mathrm{Al}$, and $\mathrm{Al}-\mathrm{O}$ bending and stretching vibrations [31-34]. Similar absorptions were observed in the spectra of $\mathrm{PMMA}-\mathrm{Al}(\mathrm{OH})_{3}$ coating and extracted 
$\mathrm{Al}(\mathrm{OH})_{3}$. The FTIR spectrum of HDPA showed absorptions at 2915 and $2849 \mathrm{~cm}^{-1}$, which were attributed to the asymmetric and symmetric stretching vibrations of $\mathrm{CH}_{2}$ and $\mathrm{CH}_{3}$ groups $[35,36]$. Similar absorptions in the spectra of extracted $\mathrm{Al}(\mathrm{OH})_{3}$ and composite coating confirmed the suggested extraction mechanism, which involved HDPA adsorption on $\mathrm{Al}(\mathrm{OH})_{3}$. The absorptions in the spectrum of $\mathrm{PMMA}-\mathrm{Al}(\mathrm{OH})_{3}$ coating showed peaks at 1725 and $1140 \mathrm{~cm}^{-1}$, which were attributed to $\mathrm{C}=\mathrm{O}$ stretching and $\mathrm{CH}_{2}$ bending, respectively, of the PMMA macromolecules in agreement with the FTIR data for pure PMMA presented in Figure 5.

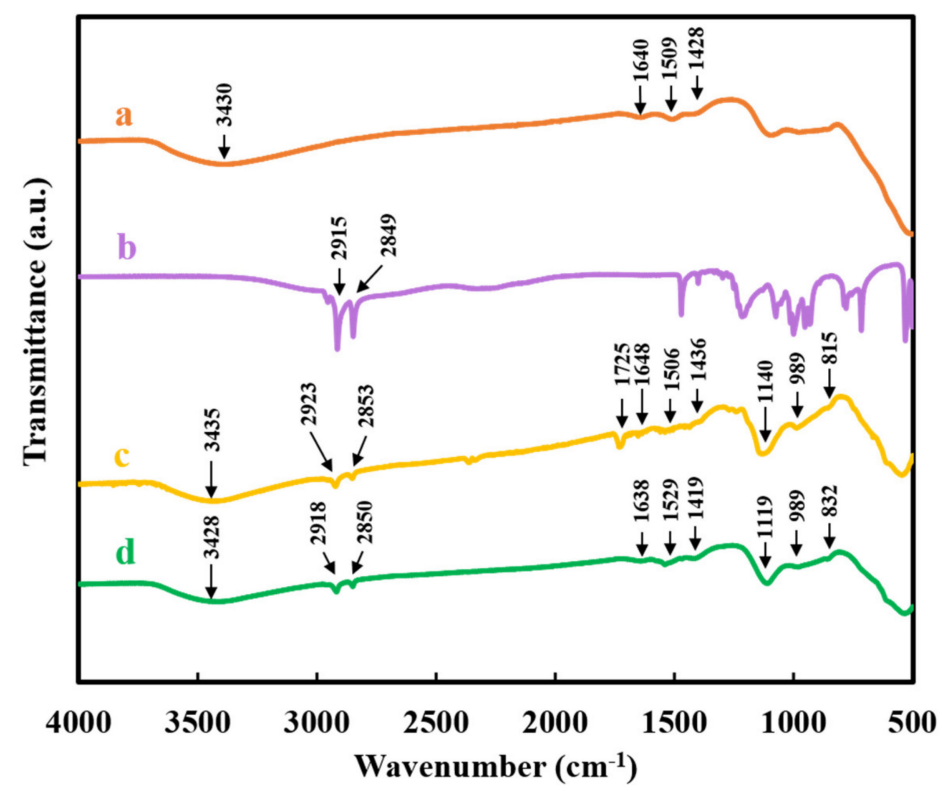

Figure 8. FTIR spectra of the (a) as-precipitated $\mathrm{Al}(\mathrm{OH})_{3}$, (b) as-received $\mathrm{HDPA},(\mathbf{c}) \mathrm{PMMA}-\mathrm{Al}(\mathrm{OH})_{3}$ coating, and (d) $\mathrm{Al}(\mathrm{OH})_{3}$ extracted using HDPA.

The results of the SEM and FTIR studies confirmed the co-deposition of $\mathrm{Al}(\mathrm{OH})_{3}$ particles and PMMA. The incorporation of inorganic particles into polymer coatings is usually based on different interactions of the particles and polymers [37,38]. Investigations [39-41] revealed interactions of the ester group of PMMA with OH groups on the surface of inorganic particles. Therefore, such interactions can facilitate the stabilization of the $\mathrm{Al}(\mathrm{OH})_{3}$ particles in PMMA solutions in the mixed water-2-propanol co-solvent and their incorporation in the PMMA matrix to form composite coatings.

\section{Materials and Methods}

Polymethyl methacrylate polymer (PMMA, $\mathrm{M}_{\mathrm{w}} \sim 350 \mathrm{kDa}$ ), $\mathrm{Al}_{2}\left(\mathrm{SO}_{4}\right)_{3} \cdot 18 \mathrm{H}_{2} \mathrm{O}$, hexadecylphosphonic acid (HDPA), halloysite $\left(\mathrm{Al}_{2} \mathrm{Si}_{2} \mathrm{O}_{5}(\mathrm{OH})_{4} \cdot 2 \mathrm{H}_{2} \mathrm{O}\right.$ nanotubes, length $1-2 \mu \mathrm{m}$, diameter 100-150 nm), hydrotalcite $\left(\mathrm{Mg}_{6} \mathrm{Al}_{2}\left(\mathrm{CO}_{3}\right)(\mathrm{OH})_{16} \cdot 4 \mathrm{H}_{2} \mathrm{O}\right.$, size $\left.\sim 0.5 \mu \mathrm{m}\right)$, 2-propanol, and $\mathrm{NaOH}$ (Aldrich) and huntite $\left(\mathrm{Mg}_{3} \mathrm{Ca}\left(\mathrm{CO}_{3}\right)_{4}\right.$ platelets, Sibelco, size $\left.\sim 0.5-3 \mu \mathrm{m}\right)$ were used as starting materials. Solutions of $0.5-20 \mathrm{~g} \mathrm{~L}^{-1}$ PMMA in water-2-propanol with different water/2-propanol ratios were prepared at $50{ }^{\circ} \mathrm{C}$ and cooled to $20^{\circ} \mathrm{C}$. FRM materials were added to the solutions, which were then ultrasonicated for $0.5 \mathrm{~h}$. The suspensions contained $10 \mathrm{~g} \mathrm{~L}^{-1}$ polymer and 1-10 $\mathrm{g} \mathrm{L}^{-1}$ halloysite, huntite, and hydrotalcite.

The synthesis and extraction of $\mathrm{Al}(\mathrm{OH})_{3}$ was performed by dissolving $2 \mathrm{~g}$ of $\mathrm{Al}_{2}\left(\mathrm{SO}_{4}\right)_{3}$.$18 \mathrm{H}_{2} \mathrm{O}$ in $50 \mathrm{~mL}$ of $\mathrm{DI} \mathrm{H}_{2} \mathrm{O}$, adjusting $\mathrm{pH}$ to $\mathrm{pH}=9$ using $\mathrm{NaOH}$, adding $100 \mathrm{mg} \mathrm{HDPA}$ in $25 \mathrm{~mL}$ isopropanol, stirring, and adding $6 \mathrm{~g} \mathrm{NaCl}$. The $\mathrm{Al}(\mathrm{OH})_{3}$ suspension in 2-propanol was separated from the aqueous phase and diluted with water in order to achieve a water-2-propanol ratio 0.25 . PMMA was added to the suspension and dissolved at $50{ }^{\circ} \mathrm{C}$.

Pure PMMA polymer solutions and FRM suspensions, containing dissolved PMMA, were used for dip coating of 304 type stainless steel foils. In a typical dip coating procedure, a substrate was immersed in the PMMA solution without FRM or with dispersed FRM, 
remained in the solution for $30 \mathrm{~s}$, and then it was withdrawn from the solution at a constant speed of $1 \mathrm{~mm} \mathrm{~s}^{-1}$. Testing was performed using a microscope JEOL SEM, Japan, (JSM7000F), Bruker USA (D8, Cu-K $\alpha$ ) X-ray diffractometer and FTIR, Vertex USA (Vertex 70) spectrometer. Coating adhesion was tested according to ASTM D3359-17 for comparison with adhesion of other polymer coatings [42-44]. The experimental details and equipment for corrosion testing in $3 \% \mathrm{NaCl}$ solutions were described in $[45,46]$.

\section{Conclusions}

This study demonstrated that despite the PMMA insolubility in 2-propanol and water, high $\mathrm{M}_{\mathrm{W}}$ PMMA was well-soluble in their mixtures with different water contents. The use of high $\mathrm{M}_{\mathrm{W}}$ PMMA and high solution concentration were key factors for the PMMA deposition by a dip coating method. The use of carcinogenic and toxic solvents for PMMA can be eliminated. The amount of the deposited PMMA can be changed by the variation of the PMMA concentration, solvent composition, and number of the deposited layers. PMMA coatings were used for the protection of stainless steel from aqueous corrosion. PMMA deposits were loaded with environmentally friendly FRM, such as commercial halloysite, huntite, and hydrotalcite, as well as synthesized $\mathrm{Al}(\mathrm{OH})_{3}$, avoiding the use of toxic halogen-based FRM. A fundamentally new strategy was developed for the fabrication of PMMA- $\mathrm{Al}(\mathrm{OH})_{3}$ coatings, which was based on the salting out aided dispersive extraction of $\mathrm{Al}(\mathrm{OH})_{3}$ particles. HDPA is a promising extractor for the particle transfer. The method allows for reduced particle agglomeration. The ability to deposit multiple PMMA layers and composite layers indicates that the dip coating method can be applied for the fabrication of multilayer coatings, containing different layers and for the deposition of coatings of graded composition. The method can potentially be applied for the deposition of composites, containing other functional organic and inorganic materials.

Author Contributions: Conceptualization, I.Z., R.M. and X.L.; methodology, X.L., S.S. and Z.W.; validation, X.L., S.S., Z.W. and R.M.; formal analysis, X.L., S.S.; investigation, X.L., S.S. and Z.W.; resources, R.M. and I.Z.; writing—original draft preparation, X.L. and I.Z.; writing-review and editing, X.L., Z.W., R.M. and I.Z.; visualization, X.L.; supervision, R.M. and I.Z.; project administration, R.M. and I.Z.; funding acquisition, R.M. and I.Z. All authors have read and agreed to the published version of the manuscript.

Funding: This research was funded by the Natural Sciences and Engineering Research Council of Canada: grant number RGPIN-2018-04014.

Institutional Review Board Statement: Not applicable.

Informed Consent Statement: Not applicable.

Data Availability Statement: The data presented in this study are available in: Poly(methyl methacrylate) coatings containing flame retardant additives from suspensions in water-2-propanol.

Acknowledgments: SEM investigations were performed at the Canadian Centre for Electron Microscopy.

Conflicts of Interest: The authors declare no conflict of interest.

\section{References}

1. Ali, U.; Karim, K.J.B.A.; Buang, N.A. A review of the properties and applications of poly (methyl methacrylate)(PMMA). Polym. Rev. 2015, 55, 678-705. [CrossRef]

2. Laoutid, F.; Bonnaud, L.; Alexandre, M.; Lopez-Cuesta, J.-M.; Dubois, P. New prospects in flame retardant polymer materials: From fundamentals to nanocomposites. Mater. Sci. Eng. R Rep. 2009, 63, 100-125. [CrossRef]

3. Jayarama Krishna, J.V.; Srivatsa Kumar, S.; Korobeinichev, O.P.; Vinu, R. Detailed kinetic analysis of slow and fast pyrolysis of poly(methyl methacrylate)-Flame retardant mixtures. Thermochim. Acta 2020, 687, 178545. [CrossRef]

4. Wong, F.; Kurt-Karakus, P.; Bidleman, T.F. Fate of brominated flame retardants and organochlorine pesticides in urban soil: Volatility and degradation. Environ. Sci. Technol. 2012, 46, 2668-2674. [CrossRef]

5. Xiao, H.; Shen, L.; Su, Y.; Barresi, E.; DeJong, M.; Hung, H.; Lei, Y.-D.; Wania, F.; Reiner, E.J.; Sverko, E. Atmospheric concentrations of halogenated flame retardants at two remote locations: The Canadian High Arctic and the Tibetan Plateau. Environ. Pollut. 2012, 161, 154-161. [CrossRef] [PubMed] 
6. Wang, Z.; Clifford, A.; Milne, J.; Mathews, R.; Zhitomirsky, I. Colloidal-electrochemical fabrication strategies for functional composites of linear polyethylenimine. J. Colloid Interface Sci. 2019, 552, 1-8. [CrossRef] [PubMed]

7. Goda, E.S.; Yoon, K.R.; El-sayed, S.H.; Hong, S.E. Halloysite nanotubes as smart flame retardant and economic reinforcing materials: A review. Thermochim. Acta 2018, 669, 173-184. [CrossRef]

8. Wang, Y.; Deen, I.; Zhitomirsky, I. Electrophoretic deposition of polyacrylic acid and composite films containing nanotubes and oxide particles. J. Colloid Interface Sci. 2011, 362, 367-374. [CrossRef]

9. Xuteng, X.; Xiaoyang, X.; Jihui, W.; Wenbin, H. Preparation, release and anticorrosion behavior of a multi-corrosion inhibitorshalloysite nanocomposite. Chem. Phys. Lett. 2019, 718, 69-73.

10. Yildirim, S.; Celik, E. Production and characterization of the halogen-free and nanostructured flame retardant reinforced composite coatings. J. Aust. Ceram. Soc. 2020, 56, 683-695. [CrossRef]

11. Savas, L.A.; Arslan, C.; Hacioglu, F.; Dogan, M. Effect of reactive and nonreactive surface modifications and compatibilizer use on mechanical and flame-retardant properties of linear low-density polyethylene filled with huntite and hydromagnesite mineral. $J$. Therm. Anal. Calorim. 2018, 134, 1657-1666. [CrossRef]

12. Erdem, A.; Dogan, M. Production and Characterization of Green Flame Retardant Poly(lactic acid) Composites. J. Polym. Environ. 2020, 28, 2837-2850. [CrossRef]

13. Zhang, T.; Luo, D.; Wojtal, P.; Zhitomirsky, I. Electrophoretic deposition of flame retardant polymer-huntite coatings. Mater. Lett. 2015, 159, 106-109. [CrossRef]

14. Du, J.-Z.; Jin, L.; Zeng, H.-Y.; Feng, B.; Xu, S.; Zhou, E.-G.; Shi, X.-K.; Liu, L.; Hu, X. Facile preparation of an efficient flame retardant and its application in ethylene vinyl acetate. Appl. Sci. 2019, 168, 96-105. [CrossRef]

15. Xu, S.; Li, S.-Y.; Zhang, M.; Zeng, H.-Y.; Wu, K.; Tian, X.-Y.; Chen, C.-R.; Pan, Y. Fabrication of green alginate-based and layered double hydroxides flame retardant for enhancing the fire retardancy properties of polypropylene. Carbohydr. Polym. 2020, 234, 115891. [CrossRef] [PubMed]

16. Xu, S.; Liao, M.-C.; Zeng, H.-Y.; Zhang, Z.-Q.; Liu, X.-J.; Zhu, P.-H. Ultrafine hydrotalcite particles prepared with novel technology to improve the flame retardancy of polypropylene. Appl. Clay Sci. 2015, 108, 215-221. [CrossRef]

17. Elbasuney, S. Novel multi-component flame retardant system based on nanoscopic aluminium-trihydroxide (ATH). Powder Technol. 2017, 305, 538-545. [CrossRef]

18. Liang, J.; Zhang, Y. A study of the flame-retardant properties of polypropylene $/ \mathrm{Al}(\mathrm{OH})_{3} / \mathrm{Mg}(\mathrm{OH})_{2}$ composites. Polym. Int. 2010, 59, 539-542. [CrossRef]

19. Silva, R.M.E.; Poon, R.; Milne, J.; Syed, A.; Zhitomirsky, I. New developments in liquid-liquid extraction, surface modification and agglomerate-free processing of inorganic particles. Adv. Colloid Interface Sci. 2018, 261, 15-27. [CrossRef]

20. Cowie, J.M.; Mohsin, M.A.; McEwen, I.J. Alcohol-water cosolvent systems for poly (methyl methacrylate). Polymer 1987, 28, 1569-1572. [CrossRef]

21. Hoogenboom, R.; Becer, C.R.; Guerrero-Sanchez, C.; Hoeppener, S.; Schubert, U.S. Solubility and thermoresponsiveness of PMMA in alcohol-water solvent mixtures. Aust. J. Chem. 2010, 63, 1173-1178. [CrossRef]

22. Zhang, Q.; Hoogenboom, R. Polymers with upper critical solution temperature behavior in alcohol/water solvent mixtures. Prog. Polym. Sci. 2015, 48, 122-142. [CrossRef]

23. Zhitomirsky, I. Cathodic electrophoretic deposition of diamond particles. Mater. Lett. 1998, 37, 72-78. [CrossRef]

24. Zhitomirsky, I.; Gal-Or, L. Formation of hollow fibers by electrophoretic deposition. Mater. Lett. 1999, 38, 10-17. [CrossRef]

25. Huszánk, R.; Szilágyi, E.; Szoboszlai, Z.; Szikszai, Z. Investigation of chemical changes in PMMA induced by $1.6 \mathrm{MeV}$ He+ irradiation by ion beam analytical methods (RBS-ERDA) and infrared spectroscopy (ATR-FTIR). Nucl. Instrum. Methods Phys. Res. B 2019, 450, 364-368. [CrossRef]

26. Li, C.; Zhao, Y.; Zhu, T.; Ruan, J.; Li, G. Effective solvent-free oxidation of cyclohexene to allylic products with oxygen by mesoporous etched halloysite nanotube supported $\mathrm{Co}^{2+}$. RSC Adv. 2018, 8, 14870-14878. [CrossRef]

27. Tian, X.; Wang, J.; Zhang, H.; Cao, Z.; Zhao, M.; Guan, Y.; Zhang, Y. Establishment of transport channels with carriers for water in reverse osmosis membrane by incorporating hydrotalcite into the polyamide layer. RSC Adv. 2018, 8, 12439-12448. [CrossRef]

28. Zhigang, T.; Rongqi, Z.; Zhanting, D. Separation of isopropanol from aqueous solution by salting-out extraction. J. Chem. Technol. Biotechnol. 2001, 76, 757-763. [CrossRef]

29. Khayati, G.; Gholitabar, A. Liquid-liquid equilibrium of hydrophilic alcohols with three different salts of chloride: Experiment and correlation. J. Chem. Eng. Data 2016, 61, 1454-1461. [CrossRef]

30. Ata, M.S.; Wojtal, P.; Zhitomirsky, I. Surface modification and electrophoretic deposition of materials using carboxyalkylphosphonic acids. Mater. Lett. 2016, 184, 320-323. [CrossRef]

31. Pouran, H.M.; Banwart, S.A.; Romero-Gonzalez, M. Coating a polystyrene well-plate surface with synthetic hematite, goethite and aluminium hydroxide for cell mineral adhesion studies in a controlled environment. Appl. Geochem. 2014, 42, 60-68. [CrossRef]

32. Liu, R.; Gong, W.; Lan, H.; Gao, Y.; Liu, H.; Qu, J. Defluoridation by freshly prepared aluminum hydroxides. Chem. Eng. J. 2011, 175, 144-149. [CrossRef]

33. Beran, A.; Voll, D.; Schneider, H. Dehydration and structural development of mullite precursors: An FTIR spectroscopic study. J. Eur. Ceram. Soc. 2001, 21, 2479-2485. [CrossRef]

34. Tokoro, C.; Suzuki, S.; Haraguchi, D.; Izawa, S. Silicate removal in aluminum hydroxide co-precipitation process. Materials 2014, 7, 1084-1096. [CrossRef] 
35. Milne, J.; Silva, R.M.; Zhitomirsky, I. Surface modification and dispersion of ceramic particles using liquid-liquid extraction method for application in supercapacitor electrodes. J. Eur. Ceram. Soc. 2019, 39, 3450-3455. [CrossRef]

36. Milne, J.; Zhitomirsky, I. Application of octanohydroxamic acid for liquid-liquid extraction of manganese oxides and fabrication of supercapacitor electrodes. J. Colloid Interface Sci. 2018, 515, 50-57. [CrossRef]

37. Zhitomirsky, I.; Petric, A. Electrochemical deposition of yttrium oxide. J. Mater. Chem. 2000, 10, 1215-1218. [CrossRef]

38. Pang, X.; Zhitomirsky, I.; Niewczas, M. Cathodic electrolytic deposition of zirconia films. Surf. Coat. Technol. 2005, 195, 138-146. [CrossRef]

39. Pletincx, S.; Marcoen, K.; Trotochaud, L.; Fockaert, L.-L.; Mol, J.M.; Head, A.R.; Karslioğlu, O.; Bluhm, H.; Terryn, H.; Hauffman, T. Unravelling the chemical influence of water on the PMMA/aluminum oxide hybrid interface in situ. Sci. Rep. 2017, 7, 13341. [CrossRef]

40. Nunnery, G.; Hershkovits, E.; Tannenbaum, A.; Tannenbaum, R. Adsorption of poly(methyl methacrylate) on concave $\mathrm{Al}_{2} \mathrm{O}_{3}$ surfaces in nanoporous membranes. Langmuir 2009, 25, 9157-9163. [CrossRef]

41. Tighilt, F.-Z.; Gabouze, N.; Sam, S.; Belhousse, S.; Beldjilali, K. Morphology and specific interaction of PMMA coating with the surface of porous silicon. Surf. Sci. 2007, 601, 4217-4221. [CrossRef]

42. Xu, Y.; Luo, J.; Liu, X.; Liu, R. Polyurethane modified epoxy acrylate resins containing $\varepsilon$-caprolactone unit. Progress Org. Coat. 2020, 141, 105543. [CrossRef]

43. Lo, T.N.; Hwang, H.S.; Lee, J.; Park, I. Synthesis of new semi-fluorinated polysilazanes and their amphiphobic coating applications. Prog. Org. Coat. 2020, 148, 105853. [CrossRef]

44. Shen, Z.; Wu, Y.; Qiu, S.; Deng, H.; Hou, R.; Zhu, Y. UV-thermal dual-cured polymers with degradable and anti-bacterial function. Prog. Org. Coat. 2020, 148, 105783. [CrossRef]

45. Deen, I.; Pang, X.; Zhitomirsky, I. Electrophoretic deposition of composite chitosan-halloysite nanotube-hydroxyapatite films. Colloids Surf. A Physicochem. Eng. Aspects 2012, 410, 38-44. [CrossRef]

46. Zhao, Q.; Liu, X.; Veldhuis, S.; Zhitomirsky, I. Sodium deoxycholate as a versatile dispersing and coating-forming agent: A new facet of electrophoretic deposition technology. Colloids Surfaces A Physicochem. Eng. Aspects 2020, 588, 124382. [CrossRef] 